\title{
GC-MS ANALYSIS OF THREE PLANTS ESSENTIAL OILS AND THEIR EFFECT ON BACTERIAL SPOT DISEASE OF TOMATO
}

\author{
G.A. Ahmed ${ }^{(1)}$, A.A. El-Sisi ${ }^{(1)}$ and M. E. Selim ${ }^{(2)}$ \\ (1) Plant Pathology Department, Faculty Agriculture, Moshtohor, Benha University. Egypt. \\ (2) Agricultural botany Department., Faculty of Agriculture, Menoufia University. Egypt.
}

Received: Aug. 24, 2021

Accepted: Sep. 9, 2021

ABSTRACT: The aim of this present study is to evaluate the antimicrobial activities of three plants essential oils, Nigella (Nigella sativa), Eucalyptus (Cinnamomum camphora) and clove (Syzygium aromaticum) against plant pathogenic bacteria Xanthomonas vesicatoria and their influences on controlling the bacterial spot disease of tomato plants. The chemical composition of the oils was calculated by gas chromatograph/mass spectrometer (GC/MS) analysis. The results revealed that the major constituents of Nigella oil were fatty acid i.e. oleic acid $(4.09 \% \%)$, Fumaric acid $(0.13 \%)$, Palmitic acid (4.95-1.65\%), Octadec-9-enoic acid (0.53\%), myristic acid $(0.78 \%)$, Cyclohexadecane $(0.01 \%)$ and Hexanedioic acid bis (2-ethylhexyl) ester $(75.02 \%)$. In addition, the main components of Eucalyptus oil were D-camphor (40.01\%), linalool (20.57\%), and cineole (10.86\%). The chemical analysis showed also that clove oil contained eugenol $(22.94 \%)$, eugenyl acetate (16.65\%), caryophyllene (10.37\%) and 2-Pyridineethanol (6.08 \%). In in vitro bioassay against $X$.anthomonas vesicatoria, the results demonstrated that among the three tested plant oils, Eucalyptus oil (10\%) recorded the maximum value was (1.73 $\mathrm{cm}$ ) bacterial inhibition zone followed by Clove oil $(1.50 \mathrm{~cm})$. Results also showed spraying plants with the tested essential oils two days before bacterial inoculation recorded the lowest disease index comparing to the treatment where plants were treating with essential oils two days after bacterial inoculation. The obtained results also clearly illustrated that, Peroxidase (PO), polyphenoloxidase PPO and chitinase activities increased as a result of spraying tomato plants with the tested oils. Moreover, protein analysis confirmed that new protein bands with low molecular weight had a progressive relationship with reduction of bacterial spot disease severity on plants treated with the tested oils.

Key words: GC/MS, Essential oils, Bacterial spot, Xanthomonas vesicatoria, Nigella sativa, Cinnamomum camphora, Syzygium aromaticum.

\section{INTRODUCTION}

Plant diseases adversely affect human health through agricultural and economic losses rather than their implications on biodiversity conservation. Bacteria and fungi are the most common cause of many plant diseases. Controlling plant diseases in general and bacterial diseases in particular depending on chemical pesticides became more difficult day after day due to many reasons i.e. the rapid pathogen populations resistant toward the chemicals, undesirable effect on the environment, slow biodegradation of many chemical groups which increasing the post-harvest intervals (PHI) and many serious side effects for mammalian health associated with toxic residues in food products. Therefore, it is necessary to develop alternative materials of combating pathogenic bacterial and fungal diseases on their host plants. Natural oils which are concentrated hydrophobic liquid consisting of volatile aromatic compounds obtained from various parts of plants are candidate to be promising alternatives for traditional 
chemical control that depending on completely synthetic compounds. It was previously known that many of these natural essential oils have many biological activities, such as antifungal and antibacterial properties (Hawthorne et al., 1993, Kokkini et al., 1997). Recently, the interest in the application of essential oils to control plant pathogens has increased therefore the effectiveness of various essential oils against many plant pathogenic bacteria and fungi was determined (Ghalem, 2016). The studies showed that the chemical composition and biological activities of plant essential oils depending on different parameters, such as the environment, the season in which aromatic plants are collected, the process of dehydration, the preservation conditions in which the collected plants are stored as essential oils (Tarantilis and Polissiou, 1997; Russo et al., 1998). The antimicrobial activity and chemical composition of many essential oils and plant extracts have been investigated by many researchers (Daferera et al., 2000). GC-MS (qualitative and quantitative) analysis is indispensable in the evaluation of the biological activity and chemical composition studies for the essential plants oil (Gorris et al., 1994 and Reddy et al., 1998). On the other hand, bacterial spot disease of tomato which is caused by Xanthomonas vesicatoria considered one of the most serious diseases effecting both foliage and fruit growth and yield. This disease can cause great damage to all plant parts including leaves, stems, and fruits with considerable reduction of quality and quantity of tomato yields (Byrnea et al., 2005). In spite of disadvantages of chemical applications such as hazardous residuals on fruits, cost, and development of resistant bacterial strains, the using of such these traditional control measurements i.e. copper or tetracycline and streptomycin antibiotic sprays were not able alone to stop the disease dispersal (Stall, 1993; El-Hendawy et al., 2005; Al-Dahmani et al., 2003). Therefore new eco-friendly and effective alternatives against Xanthomonas vesicatoria such as biological control and natural plant essential oils are gaining more importance and attracting scientist attentions during the recent years. Many substances such as Garlic extract (Allium sativum), Mentha oil (Mentha aquatica), clove oils (Syzygium aromaticum) as well as resistant acids like ascorbic acid and salicylic acid were investigated to determine either their antimicrobial activities toward different plant pathogenic organisms or to identify their chemical composition (Abd El-Ghafar and Abd El-Wahab, 2001; Polizzi et al., 2002; Morais et al., 2002; Pietro et al., 2004; Balestra et al., 2009).

The aims of present study are to evaluate the antimicrobial activities and chemical composition of three plants essential oils Nigella (Nigella sativa), Eucalyptus (Cinnamomum camphora) and clove (Syzygium aromaticum) against plant pathogenic bacteria Xanthomonas vesicatoria under in vitro and in vivo conditions.

\section{MATERIALS AND METHODS}

\section{Bacterial inoculum preparation}

$X$. vesicatoria used in this study was provided by Plant Pathology Research Institute., Agricultural Research Center (ARC), Giza, Egypt and was routinely grown on nutrient agar (NA) at $28^{\circ} \mathrm{C}$. The strain cultures growing on nutrient broth media containing $10 \%$ glycerol was stored at $-20^{\circ} \mathrm{C}$ and regenerated twice before use in the experiments. Bacterial cultures were suspended in sterile distilled water and turbidity was adjusted to an OD $630 \mathrm{~nm} \quad 0.100$ using a spectrophotometer (SPECTRONIC 20-D), corresponding to a cell concentration of 
ca.10 $\mathrm{CFU} / \mathrm{ml}$ (Altundag and Aslim, 2011).

\section{Collection of essential oils:}

Three different oils i.e. Nigella (Nigella sativa) oil, Eucalyptus (Cinnamomum camphora) oil and Clove (Syzygium aromaticum) oil were obtained kindly from the Sector of Perfume and Additives, Hawamdia Sugar Company, Cairo, Egypt. Two different concentrations 5 and $10 \%$ of oils were prepared using dilution with sterilized skimmed milk powder (1\%) according to Chowdappa et al. (2018) method.

\section{Disc Diffusion Assay:}

This experiment was conducted in a completely randomized block design with three replicates to investigate the efficacy of the three tested oils i.e. Nigella oil, Eucalyptus oil and Clove oil with two concentrations 5 and $10 \%$ on $X$. vesicatoria bacteria under in vitro conditions. Filter paper discs (Whatman No.1, $7 \mathrm{~mm}$ in diameter) were saturated with the different concentrations of the tested oils. The discs were then placed on the surface of the medium previously inoculated with tested pathogenic bacteria, using appropriate amounts of 24 hrs old nutrient broth culture as inoculum. The plates were incubated at $28 \pm 2^{\circ} \mathrm{C}$ for 2 days. The degree of inhibitory action was estimated by measuring the diameter of the zone of inhibited growth surrounding the disc.

\section{Effect of the tested essential oils under greenhouse condition:}

The efficiency of tested essential oils was conducted in the greenhouse to study their effect in reducing the severity bacterial spot disease of tomato (Solanum lycopersicum) cultivar Super Strain B seedlings (from Qaha nurseries (El-Qalubia). The experiment was conducted in a randomized complete block design, with three replicates and three plants per pot. Thirty $\mathrm{ml}$ of each essential oil was kept in $100 \mathrm{ml}$ conical flask $(1.5 \mathrm{ml}$ essential oil $10 \%+30 \mathrm{ml}$ of distilled water $+1 \mu \mathrm{l}$ of Tween 80 ) and kept at shaker for $24 \mathrm{~h}$ for continuous agitation at $150 \mathrm{rev} / \mathrm{min}$ for thorough mixing and complete elucidation of active materials to dissolve in the respective solvent (Bagy and Abo-Elyousr, 2019). The plants (21-day-old seedlings) were divided into two groups. The first group was inoculated with the pathogen $X$. vesicatoria at concentration of $\mathrm{ca} .10^{8}$ $\mathrm{CFU} / \mathrm{ml}$, two days after application with essential oils ( $30 \mathrm{ml}$ of each essential oil). Plants in the second group, plants were inoculated with spraying the pathogenic bacteria two days before application of essential oils and control plants sprayed with water. After the treatment, tomato seedlings were covered with plastic bags for $48 \mathrm{~h}$. The experiment was carried out in three replicates. Disease severity and disease rate were calculated according to formula by Towsend and Heuberger (1943):

Disease severity $(\%)=$

$\frac{\Sigma \text { [disezse plant number of exch scale x scale value) }}{4 \text { xtotal plant number }} \times 100$

For disease severity (magnitude of symptom shown by inoculated plants) the empirical scale: $0=$ No symptoms; 1 $=1 / 4$ of the plants show symptoms; $2=$ half of the plants show symptoms; $3=3 / 4$ of the plants show symptoms; $4=$ all plants show symptoms. (Altundag and Aslim, 2011).

\section{Gas chromatography/mass spectrometry analysis.}

The chemical composition of the tested oils was analyzed by GC mass. The mass spectrometer was Agilent 6890 Series II gas chromatography. An Agilent 5973 mass spectrometer (Mode EI generated at $70 \mathrm{eV}$, ion source at $230^{\circ} \mathrm{C}$ and transfer line at $280^{\circ} \mathrm{C}$ ) with electron 
G.A. Ahmed, et al.,

ionization was used. The GC was performed using HP5 -MS capillary column $(30 \mathrm{~m} \times 0.25 \mathrm{~mm} \times 0.25 \mu \mathrm{m})$. Operating conditions were as follows: carrier gas, helium with a flow rate of (1 $\mathrm{mL}$ min-1). The initial temperature was programmed from $60 \circ \mathrm{C}$ to 290 ramp $8{ }^{\circ} \mathrm{C}$ min-1. Helium (99.99\%) was the carrier gas at a flow rate of $1 \mathrm{ml} / \mathrm{min}$. Diluted samples $(1 / 100$ in hexane, $v / v)$ of $1.0 \mu l$ were injected manually. Identification of the components was based on the comparison of their mass spectra with those of Wiley7N, Nist 2002 and Flavor libraries and comparison of their retention times (Tabanca et al., 2001; Aligiannis et al., 2001).

\section{Determining of enzyme activities:}

Leaves sample of treated tomato plants (cv. Super Strain B) with different treatments under study in greenhouse were taken 30 days after transplanting. Leaf samples were ground with $0.2 \mathrm{M}$ Tris $\mathrm{HCl}$ buffer (pH 7.8) containing $14 \mathrm{mM} \beta$ mercaptoethanol at the rate $1 / 3 \mathrm{w} / \mathrm{v}$. The extracts were centrifuged at $10,000 \mathrm{rpm}$ for $20 \mathrm{~min}$ at $4^{\circ} \mathrm{C}$. The supernatant layer was used to determine enzyme activities (Tuzun et al., 1989).

\subsection{Determination of Peroxidase (PO):}

Peroxidase activity was determined according to the method described by Allam and Hollis (1972).

\section{2. \\ Determination Polyphenoloxidase (PPO): \\ of}

The polyphenoloxidase activity was determined according to the method described by Matta and Dimond (1963).

\subsection{Determination of chitinase}

Determination of the activity of chitinase was carried out according to the method of Boller and Mauch, (1988).

\section{Sodium dodecyl sulfate- polyacrylamide gel electrophoresis (SDS-PAGE):}

Eighty-microliters ( $80 \mu \mathrm{L}$ of protein) of leaves samples were subjected to SDSpolyacrylamide gel electrophoresis was performed in $12 \%$ acrylamide slab gels following the system of Laemmli (1970) to identify their protein profiles. Gels were photographed scanned, analyzed using Gel Doc VILBER LOURMAT system.

\section{Data analysis:}

All obtained data were analyzed using analysis of variance (ANOVA) among treatments. Means were compared by least significant differences (LSD) at $p$ $\leq 0.05$ as described by Song and Keane (2006).

\section{RESULT AND DISCUSSION:}

1. In vitro growth inhibition of three essential oils against xanthomonas vesicatoria:

The influences of the three tested plant oils against of $X$. vesicatoria under in vitro condition were evaluated. The obtained results indicated that most of the tested plant oils inhibited the growth of this pathogenic plant bacteria at both concentrations tested $(5 \& 10 \%)$ as shown in Table 1. The growth inhibition was positively correlated with the concentrations of oils. Among all treatments, Eucalyptus oil (10 \%) recorded the maximum inhibition zone $(1.73 \mathrm{~cm})$ followed by Clove oil $(1.50 \mathrm{~cm})$. These results are in a line with Chowdappa et al., (2018) who reported also that clove oil was the most effective oil against Xanthomonas axonopodis with an inhibition zone of $27.3 \mathrm{~mm}$ at concentration of $40 \%$. Moreover, they added that Clove oil was still effective against bacteria even at concentration of $10 \%$. Current finding is agreeing with Gilvaine et al. (2012) who mentioned that $10 \%$ thyme oil showed a toxic effect on 
the Xanthomonas campestris pv. vesicatoria. Similar reports were made by Gill and Holley 2006; Carson et al., 1995 and Bagamboula et al., 2004.

2. Effect of the tested essential oils on diseases severity of Xanthomonas vesicatoria under greenhouse condition:

Data in Table 2 reveal spraying plants with the tested essential oils two days before bacterial inoculation recorded the lowest disease severity comparing to the treatment where plants were treating with essential oils two days after bacterial inoculation. Noteworthy, the results showed that the lowest disease severity
(7\%) was recorded with Eucalyptus oil either in both treatments where plants were treated two days before or after bacterial inoculation. Current finding is agreeing with Da Silva et al., (2019) who demonstrated that Lippia gracilis essential oils have antimicrobial activity and have a potential to be used in the control of black rot caused by $X$. campestris pv. campestris. Different components have been reported as effective compounds against Xanthomonas campestris i.e. eugenol, Cinnamomum cassia, Cinnamomum zeylanicum, Syzygium aromaticum (Cantore et al., 2009; Chudasama and Thaker, 2012).

Table 1. In vitro growth inhibition of three essential oils against xanthomonas vesicatoria.

\begin{tabular}{|l|l|c|c|}
\hline \multirow{2}{*}{ Common name } & \multicolumn{2}{|c|}{ Essential oils } & \multicolumn{2}{c|}{ Inhibition zone (cm) } \\
\cline { 2 - 4 } & & $5 \%$ & $10 \%$ \\
\hline Eucalyptus & Cinnamomum camphora & 1.42 & 1.73 \\
\hline Clove & Syzygium aromaticum & 1.21 & 1.50 \\
\hline Nigella & Nigella sativa & 0.98 & 1.0 \\
\hline Control & Sterile distilled water & 0.0 & 0.0 \\
\hline L.S.D 0.05 $=$ & Oils & Concentrations & Interaction \\
\cline { 2 - 4 } & 0.10 & 0.05 & 0.10 \\
\hline
\end{tabular}

Table 2. Disease severity recorded on tomato plants treated with three essential oil two days before and two days after inoculation with Xanthomonas vesicatoria bacteria under greenhouse conditions.

\begin{tabular}{|l|c|c|c|c|}
\hline \multirow{2}{*}{ Treatment } & \multirow{2}{*}{$\begin{array}{c}\text { Two days } \\
\text { before (\%) }\end{array}$} & $\begin{array}{c}\text { Two days after } \\
(\%)^{\star *}\end{array}$ & & \multicolumn{2}{c|}{ Efficacy } \\
\cline { 3 - 5 } & & & $\begin{array}{c}\text { Two days } \\
\text { before (\%) }\end{array}$ & $\begin{array}{c}\text { Two days } \\
\text { after (\%) }\end{array}$ \\
\hline Eucalyptus oil & 7.0 & 7.0 & -90.67 & -91.46 \\
\hline Clove oil & 16.0 & 22.0 & -78.67 & -73.17 \\
\hline Nigella oil & 26.0 & 29.0 & -65.33 & -64.63 \\
\hline Infected Control & 75.0 & 82.0 & 0.00 & 0.00 \\
\hline Healthy control & 0.0 & 0.0 & -100.00 & -100.00 \\
\hline L.S.D 0.05\% = & Oils & Time & Interaction & \multirow{2}{*}{} \\
\cline { 2 - 4 } & 2.15 & 0.8 & 1.77 &
\end{tabular}

* Inoculated with Xanthomonas vesicatoria two days before spraying with essential oils

** Inoculated with Xanthomonas vesicatoria two days after spraying with essential oils 


\section{Chemical composition of oils}

Based on the chemical analysis conducted using GC-MS, the results showed that different number of compounds ranged from 9-23 was detected within the three tested oils (Tables 3, 4 and 5). The chemical compositions of Nigella sativa oil identified by GC-MS showed that among 9 different detected compounds, Hexanedioic acid bis (2-ethylhexyl) ester was representing (75\%) from the total detected chemical substances followed by Palmitic acid (4.95\%) and Oleic Acid (4.09\%), respectively (Table 3). These results are in a line with Muhialdin et al., (2016) who studied the chemical properties of $\boldsymbol{N}$. sativa oil using SFE and cold press extractions reported that free fatty acid and peroxide value can be used as good indicators to monitor the quality of this oil. Khoddami et al., (2011) and Solati et al., (2014) investigated also Nigella sativa oil. They detected different compounds i.e. lipids, water, protein was and carbohydrate. They reported also the chemical composition is related to the oil quality. On the other hand, some oil components such as Lauric acid, palmitic acid, linolenic acid, linoleic acid, oleic acid, stearic acid and myristic acid are known to have potential antibacterial and antifungal agents (McGaw et al., 2002 and Seidel and Taylor, 2004).

The chemical compositions of Syzygium aromaticum oil identified by GC-MS are listed in Table 4. In general, the main compounds identified in Clove oil contained eugenol (22.94\%), eugenyl acetate (16.65 \%), caryophyllene (10.37 $\%)$ and 2-Pyridineethanol (6.08 \%). Lo Cantore et al., 2009 tested the antimicrobial activity of clove oil. They found that clove oil highly reduced $X$. campestris infection under in vivo conditions. In particular, clove oil at 4 $\mathrm{mg} / \mathrm{mL}$ disinfect seeds bearing about 7.0 $\times 10^{2} \mathrm{cfu} / \mathrm{seed}$ and lower densities. However, after $72 \mathrm{~h}$, incubation treatments with 2,4 , and $8 \mathrm{mg} / \mathrm{mL}$ of clove oil caused reduction of $3 \%, 7 \%$, and $16 \%$, respectively compared to controls.

Table 3: GC-MS identification of chemical composition for Nigella (Nigella sativa) oil.

\begin{tabular}{|c|l|c|c|}
\hline Peak No. & \multicolumn{1}{|c|}{ Compound name } & $\begin{array}{c}\text { Retention } \\
\text { time (min.) }\end{array}$ & $\begin{array}{c}\text { Peak area } \\
(\%)\end{array}$ \\
\hline 1 & Palmitic acid & 8.365 & 4.95 \\
\hline 2 & Myristic acid & 15.132 & 0.78 \\
\hline 3 & Cyclohexadecane & 16.894 & 0.10 \\
\hline 4 & Palmitic acid & 17.186 & 1.65 \\
\hline 5 & Oleic Acid & 17.483 & 4.09 \\
\hline 6 & Octadec-9-enoic acid & 19.423 & 0.53 \\
\hline 7 & Fumaric acid & 20.979 & 0.13 \\
\hline 8 & Hexanedioic acid bis (2-ethylhexyl) ester & 22.336 & 75.02 \\
\hline 9 & Methyl pentadecyl ether pentan & 22.942 & 0.31 \\
\hline Total & & & 87.56 \\
\hline unknown & & & 12.44 \\
\hline
\end{tabular}


Table 4: GC-MS identification of chemical composition for clove (Syzygium aromaticum) oil.

\begin{tabular}{|c|c|c|c|}
\hline Peak No. & Compound name & $\begin{array}{c}\text { Retention } \\
\text { time } \\
\text { (min.) }\end{array}$ & $\begin{array}{c}\text { Peak } \\
\text { area }(\%)\end{array}$ \\
\hline 1 & Caryophyllene & 5.971 & 10.73 \\
\hline 2 & 6H- [1] Benzothiopyrano[4,3-b] quinoline & 8.443 & 3.23 \\
\hline 3 & 2-Pyridineethanol & 8.506 & 6.08 \\
\hline 4 & 4H-Pyrrolo[2,3-b] quinoxaline-4-carboxylic acid & 10.926 & 2.08 \\
\hline 5 & 1,1-Cyclopropanedicarbonitrile, 2,3-dimethyl- & 12.402 & 4.45 \\
\hline 6 & Anthra[2,3-b] furan-4,11-dione & 13.163 & 0.82 \\
\hline 7 & 1-Dodecene & 19.028 & 1.65 \\
\hline 8 & eugenol & 20.848 & 22.94 \\
\hline 9 & eugenyl acetate & 20.865 & 16.65 \\
\hline 10 & methyl ester 2-Cyclohexen-1-one & 21.935 & 0.72 \\
\hline 11 & $\begin{array}{l}\text { 3-Methoxy-2,4,5-trifluorobenzoic acid, tetradecyl } \\
\text { ester }\end{array}$ & 21.975 & 0.37 \\
\hline 12 & 4-Dimethylamino-2-(trimethylsilyl) benzaldehyde & 22.158 & 0.69 \\
\hline 13 & Phenanthrene, 1,7-dimethyl- & 22.238 & 1.19 \\
\hline 14 & 6-Phenylisoquinoline & 22.301 & 3.84 \\
\hline 15 & Terephthalic acid, but-2-enyl isobutyl ester & 22.313 & 1.56 \\
\hline 16 & 1,7 1-Dimethylphenanthrene & 22.570 & 0.93 \\
\hline 17 & 3-phenyl-1,2,4-triazolo[3,4-b] [1,3] benzothiazin-5-one & 22.605 & 0.74 \\
\hline 18 & $\mathrm{~N}, \mathrm{~N}-\mathrm{Di}$ (trimethylsilylmethyl)benzylamine & 22.645 & 0.62 \\
\hline 19 & Diethyl [4-(dimethylamino)phenyl] propanedioate & 22.690 & 0.60 \\
\hline 20 & $\begin{array}{l}\text { (Z)-2-(3-PHENYL-1-INDOLIZINYL)-1-P HENYL-1-VINYL } \\
\text { ACETATE }\end{array}$ & 22.828 & 3.07 \\
\hline 21 & Benzenamine, 3,5-bis(1,1-dimethylethyl)- & 22.908 & 2.43 \\
\hline 22 & 6-Chloro-2,3-dihydrofuro(2,3-b) quinoline & 22.931 & 1.15 \\
\hline 23 & Quinoline & 22.959 & 1.42 \\
\hline Total & & & 87.96 \\
\hline unknown & & & 12.04 \\
\hline
\end{tabular}

The chemical compositions of Cinnamomum camphora oil identified by GC-MS are listed in Table 5. In total, 23 constituents were identified in these essential, the main components were identified as be D-camphor $(40.01 \%)$, linalool $(20.57 \%)$, and cineole $(10.86 \%)$. The varieties of Cinnamomum camphora can be morphologically similar, but they are differed in their chemical compositions and for this reason are considerate physiological varieties
(Güenther, 1950). The traditional oils are obtained from the wood and bark (Pandey et al., 1997). The oil with a high content of camphor has an important antifungal activity (Takaoka et al., 1976). The Eucalyptus content was similar to that described for Pakistan (Sattar et al., 1991). In this the product is similar to the most common compositions described in the literature (Lin and Hua, 1987; Tao et al., 1987; Fujita et al., 1974; Dung et al., 1993 and Frizzo et al., 2000). 
G.A. Ahmed, et al.,

Table 5: GC-MS identification of chemical composition for Eucalyptus (Cinnamomum camphora) oil.

\begin{tabular}{|c|c|c|c|}
\hline Peak No. & Compound name & $\begin{array}{l}\text { Retention } \\
\text { time (min.) }\end{array}$ & $\begin{array}{c}\text { Peak } \\
\text { area (\%) }\end{array}$ \\
\hline 1 & $\begin{array}{l}\text { Propanenitrile, 3-(6-bromo-3,4- } \\
\text { methylenedioxybenzylidenhydrazino)-3-oxo- }\end{array}$ & 8.528 & 2.00 \\
\hline 2 & $\begin{array}{l}{[1,2,4] \text { Triazolo[3,4-b][1,3,4] thiadiazole, } 6-[2-(4-} \\
\text { fluorophenyl) ethenyl]-3-(4-pyridinyl)- }\end{array}$ & 10.382 & 0.99 \\
\hline 3 & Undecanal, 3-phenyl- & 10.811 & 0.51 \\
\hline 4 & 4-Cyclohexylcarbonyl-1,3-dimethylbenzene & 10.943 & 1.55 \\
\hline 5 & 1-Undecene & 13.987 & 0.43 \\
\hline 6 & 4H-Quinolizine-1,2-dicarboxylic acid, & 14.725 & 0.80 \\
\hline 7 & D-camphor & 19.240 & 40.01 \\
\hline 8 & 2-(imidazo[1,2-a] pyrimidin-2-ylmethyl)- & 19.841 & 1.26 \\
\hline 9 & 5H-Dibenzo[a,d]cycloheptene, & 20.733 & 1.91 \\
\hline 10 & 2,2'-Bi(bicyclo[2.2.1]heptane) & 20.768 & 1.37 \\
\hline 11 & 1,4-Naphthalenedione, 2-hydroxy-3-methoxy & 21.117 & 1.49 \\
\hline 12 & [1,1'-Biphenyl]-4-ol, 4'-chloro- acetate & 21.471 & 0.37 \\
\hline 13 & 2-Pyrroline-3-carboxylic & 21.552 & 1.23 \\
\hline 14 & 5H-Dibenzo[a,d]cycloheptene & 21.700 & 1.49 \\
\hline 15 & (E)-Ethyl 3-oxo-2-(pyrid-2-yl) methylene-butanoate & 21.820 & 1.33 \\
\hline 16 & Naphthalene, 1-phenyl- & 21.849 & 1.09 \\
\hline 17 & Tetracyano-p-quinodimethane & 22.129 & 1.25 \\
\hline 18 & Diethyl anilino methylene esuccinate & 22.238 & 0.85 \\
\hline 19 & cineole & 22.330 & 10.86 \\
\hline 20 & Naphthalene, 2-phenyl & 22.450 & 1.08 \\
\hline 21 & linalool & 22.633 & 20.57 \\
\hline 22 & $\begin{array}{l}\text { 2-Propenoic acid, 2-cyano-3-(3-phenylphenyl)-, } \\
\text { ethyl ester }\end{array}$ & 23.051 & 1.53 \\
\hline 23 & 1-(2-Acetyl-3-chlorophenyl)-1H-pyridin-2-one & 23.440 & 1.72 \\
\hline Total & & & 97.05 \\
\hline unknown & & & 2.95 \\
\hline
\end{tabular}

4. Effect of the tested essential oils on the activity of Peroxidase, Polyphenoloxidase and Chitinase enzymes in tomato plants.

Data in Table (6) show that enzymes activity increased in general as a result of treating tomato plants with the three tested oils compared to untreated plants. For Peroxidase enzyme, spraying plants with Eucalyptus oil followed by Nigella oil and then Clove oil two days before bacterial inoculations increased the Peroxidase activity (Table 6). On the other hand, two days after bacterial inoculations, the highest peroxidase activity was recorded on plants treated with Clove oil followed by Eucalyptus oil and then Nigella oil, respectively (Table 6). Moreover, Clove oil followed by Eucalyptus oil and then Nigella oil increased the activity of Polyphenol oxidase in both treatments. With Chitinase enzyme, Eucalyptus oil followed by Nigella oil and then Clove oil recorded the highest activity of the enzyme in treated plants two days before bacterial inoculation. The obtained 
results in the current study are agreed with other studies (Ali, 2011 and Lucas et al., 2012). According to Ali (2011) treating the tomato plants with ascorbic acid and salicylic acid reduced disease severity of $X$. vesicatoria and increasing the activity of peroxidase and polyphenoloxidase enzymes. Lucas et al., 2012 found that essential oil extracted from clove reduced the severity of tomato bacterial spot and resulted in increasing the activities of $\beta-1,3$ glucanase, chitinase, and peroxidase. Furthermore, treating pepper plants with some phenolic compounds reduced growth of Xanthomonas vesicatoria and reduced disease severity of $X$. vesicatoria and increasing the activity of peroxidase and polyphenoloxidase, chitinase and $\beta-1,3$-glucanase (Ahmed, 2016).

\section{Sodium dodecyl sulfate- polyacrylamide gel electrophoresis (SDS-PAGE):}

Concerning the results of SDS (PAGE) presented in Table (7) and demonstrated in Fig. 1 show that 14 protein bands with molecular weights ranging from 288 to 15 $\mathrm{kDa}$ were detected in tomato plants. While protein band with molecular weight 26 was appeared only in tomato treated with clove oil 2 days before inoculation with pathogen. Moreover, protein band with molecular weight 181 was absent in control plants inoculated with bacteria only and protein band with molecular weight 133 was absent in untreated and un-inoculated control. Whereas, protein band with molecular weight 88 was absent in two controls. The obtained results confirmed that new protein bands with low molecular weight had a progressive relationship on reducing disease severity of bacterial spot. Similar results were obtained by (Ahmed, 2016), who found that, new protein bands expressed as a result of treating pepper plants with phenolic inducers against bacterial spot disease. Treating pepper plants with SA-based products reduced growth of Xanthomonas vesicatoria and plant disease symptoms following challenge and are related to induction of pathogenesis-related (PR) genes (Ward et al., 1991).

Table 6. Effect of the tested essential oils on the activity of Peroxidase, Polyphenoloxidase and Chitinase enzymes in tomato plants.

\begin{tabular}{|c|c|c|c|c|}
\hline \multicolumn{2}{|c|}{ Treatment } & Peroxidase & Polyphenol oxidase & Chitinase \\
\hline Eucalyptus oil & \multirow{3}{*}{ 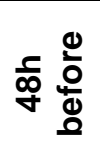 } & 25.4 & 6.58 & 9.00 \\
\hline Clove oil & & 21.2 & 6.98 & 5.36 \\
\hline Nigella oil & & 24.0 & 5.92 & 5.72 \\
\hline Eucalyptus oil & \multirow{3}{*}{ 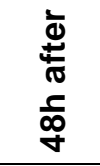 } & 24.4 & 11.36 & 13.8 \\
\hline Clove oil & & 32.0 & 14.04 & 3.63 \\
\hline Nigella oil & & 20.3 & 9.00 & 4.66 \\
\hline \multicolumn{2}{|l|}{ Control * } & 15.4 & 5.56 & 1.71 \\
\hline \multicolumn{2}{|l|}{ Control ** } & 17.3 & 5.36 & 2.36 \\
\hline
\end{tabular}

*Peroxidase activity was expressed as the increase in absorbance at $425 \mathrm{~nm} / \mathrm{gram}$ fresh weight/15 minutes.

* Polyphenoloxidase activity was expressed as the increase in absorbance at $420 \mathrm{~nm} / \mathrm{g}$ fresh weigh/ minutes

* Chitinase activity was expressed as $\mathrm{mM} \mathrm{N}$-acetylglucose amine released/g fresh weight tissue/60 minutes. 
G.A. Ahmed, et al.,

Table (7): Molecular weights of fractionated protein profiles of tomato treated with essential oils.

\begin{tabular}{|c|c|c|c|c|c|c|c|c|c|}
\hline $\begin{array}{c}\text { Band } \\
\text { No }\end{array}$ & $\begin{array}{c}\text { M.W } \\
\text { bp }\end{array}$ & Control 1 & Control 2 & $\begin{array}{c}\text { Eucalyptus } \\
\text { oil 1 }\end{array}$ & $\begin{array}{c}\text { Clove } \\
\text { oil 1 }\end{array}$ & $\begin{array}{c}\text { Nigella } \\
\text { oil 1 }\end{array}$ & $\begin{array}{c}\text { Eucalyptus } \\
\text { oil 2 }\end{array}$ & $\begin{array}{c}\text { Clove } \\
\text { oil 2 }\end{array}$ & $\begin{array}{c}\text { Nigella } \\
\text { oil 2 }\end{array}$ \\
\hline 1 & 288 & 1 & 1 & 1 & 1 & 1 & 1 & 1 & 1 \\
\hline 2 & 226 & 1 & 1 & 1 & 1 & 1 & 1 & 1 & 1 \\
\hline 3 & 181 & 0 & 1 & 1 & 1 & 1 & 1 & 1 & 1 \\
\hline 4 & 133 & 1 & 0 & 1 & 1 & 1 & 1 & 1 & 1 \\
\hline 5 & 114 & 1 & 1 & 1 & 1 & 1 & 1 & 1 & 1 \\
\hline 6 & 88 & 0 & 0 & 1 & 1 & 1 & 1 & 1 & 1 \\
\hline 7 & 70 & 1 & 1 & 1 & 1 & 1 & 1 & 1 & 1 \\
\hline 8 & 53 & 1 & 1 & 1 & 1 & 1 & 1 & 1 & 1 \\
\hline 9 & 44 & 1 & 1 & 1 & 1 & 1 & 1 & 1 & 1 \\
\hline 10 & 26 & 0 & 0 & 0 & 0 & 0 & 0 & 1 & 0 \\
\hline 11 & 25 & 1 & 1 & 1 & 1 & 1 & 1 & 1 & 1 \\
\hline 12 & 21 & 1 & 1 & 1 & 1 & 1 & 1 & 1 & 1 \\
\hline 13 & 18 & 1 & 1 & 1 & 1 & 1 & 1 & 1 & 1 \\
\hline 14 & 15 & 1 & 1 & 1 & 1 & 1 & 1 & 1 & 1 \\
\hline \multicolumn{2}{|c|}{ Total } & 11 & 11 & 13 & 14 & 13 & 13 & 14 & 13 \\
\hline
\end{tabular}

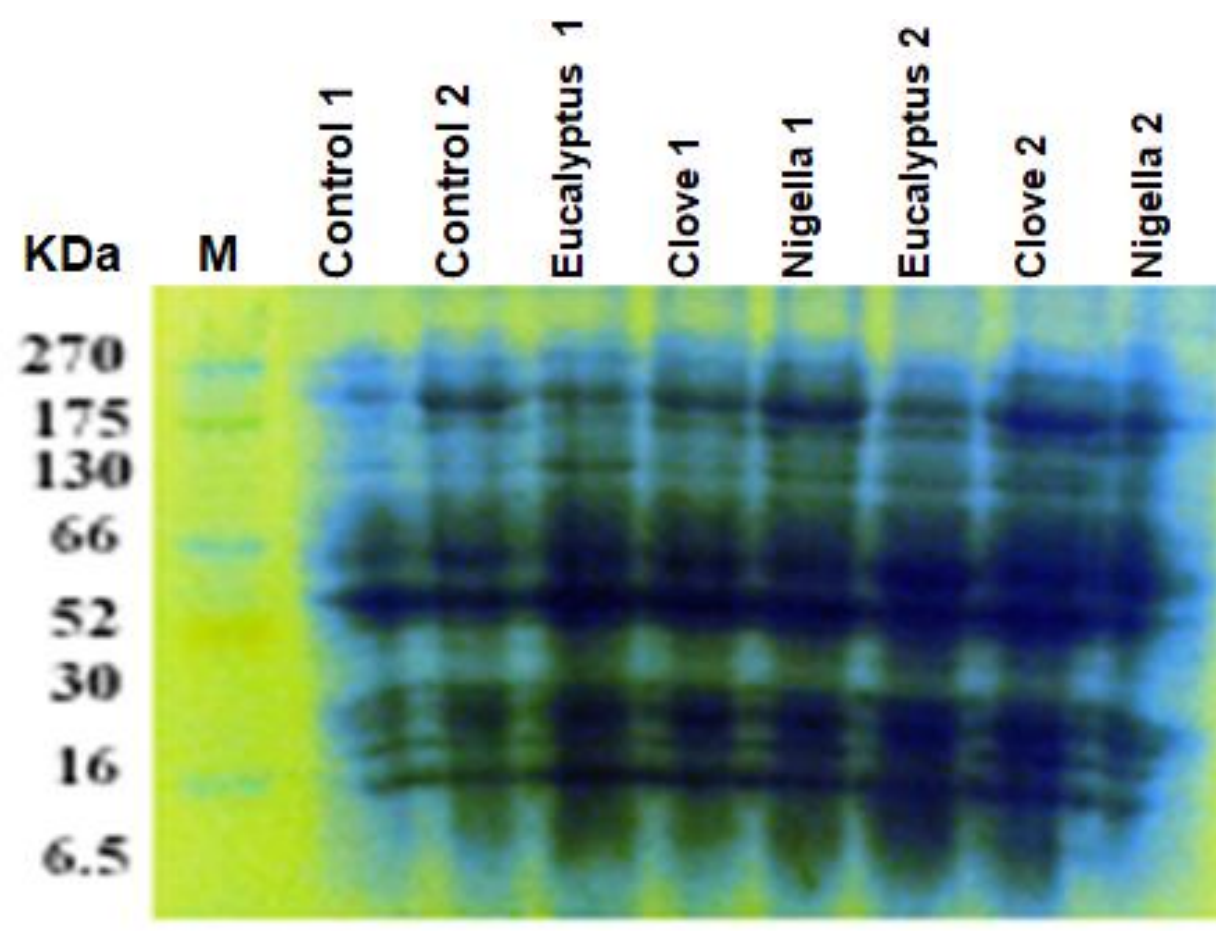

Fig. 1. Effect of treating tomato with essential oils on PAGE of protein 


\section{REFERENCES}

Abd El-Ghafar, N.Y. and H.M.A. Abd ElWahab (2001). Bacterial spot of tomato in Egypt and its control. Egypt. J. Appl. Sci., 16: 13-29.

Ahmed, G. A. (2016). Evaluation the efficacy of some phenolic compounds in controlling bacterial spot disease and biochemical changes associated in pepper plants under greenhouse conditions. J. Plant Prot. and Path., Mansoura Univ., 7 (10): 655- 662.

Al-Dahmani, J. H., P. A. Abbasi, S. A. Miller and H. A. Hoitink (2003). Suppression of bacterial spot of tomato with foliar sprays of compost extracts under greenhouse and field conditions. Plant disease, 87(8): 913919.

Ali, E.O.H. (2011). Biological and chemical control of bacterial diseases infecting tomato plants. Ph, D. Thesis, Fac. Agric., Moshtohor, Benha Univ.pp.166.

Aligiannis, N., E. Kalpoutzakis, S. Mitaku and I. B. Chinou (2001). Composition and antimicrobial activity of the essential oils of two Origanum species. Journal of agricultural and food chemistry, 49(9): 4168-4170.

Allam, A.I. and J.P. Hollis (1972). Sulfide inhibition of oxidase in rice roots. Phytopathology. 62: 634-639.

Altundag, S. and B. Aslim (2011). Effect of some endemic plants' essential oils on bacterial spot of tomato. Journal of Plant Pathology, 37-41.

Bagamboula, C. F., M. Uyttendaele and J. Debevere (2004). Inhibitory effect of thyme and basil essential oils, carvacrol, thymol, estragol, linalool and p-cymene towards Shigella sonnei and $S$. flexneri. Food microbiology, 21(1): 33-42.

Bagy, H. M. K. and K. A. Abo-Elyousr (2019). Antibacterial activity of some essential oils on bacterial spot disease of tomato plant caused by Xanthomonas axonopodis pv. vesicatoria. International Journal of Phytopathology, 8(2): 53-61.

Balestra, G.M., A. Heydari, D. Ceccarelli, E. Ovidi and A. Quattrucci (2009). Antibacterial effect of Allium sativum and Ficus carica extracts on tomato bacterial pathogens. Crop Protection, 28: 807-811.

Boller, T. and F. Mauch (1988). Chitinase from Phaseolus vulguris, leaves". Meth. Enzymol, 161: 479 - 484.

Byrnea, J.M., A.C. Dianesea, P. Ji, H.L. Campbell, D.A. Cuppels, F.J. Louws, S.A. Miller, J.B. Jones and M. Wilsona (2005). Biological control of bacterial spot of tomato under Weld conditions at several locations in North America. Biological Control, 32: 408-418.

Carson, C. F., B. D. Cookson, H. D. Farrelly and T. V. Riley (1995). Susceptibility of methicillin-resistant Staphylococcus aureus to the essential oil of Melaleuca alternifolia. Journal of Antimicrobial Chemotherapy, 35(3): 421-424.

Chowdappa, A., S. Kousalya, A. Kamalakannan, C. Gopalakrishnan and K. Venkatesan (2018). Efficacy of Plant Oils against Xanthomonas axonopodis pv. punicae. Advances in Research, 1-5.

Chudasama, K. S. and V.S. Thaker (2012). Screening of potential antimicrobial compounds against Xanthomonas campestris from 100 essential oils of aromatic plants used in India: an ecofriendly approach, Archives of Phytopathology And Plant Protection, 45(7): 783-795

Da Silva, R. S., M. M. G. de Oliveira, J. O. de Melo, A. F. Blank, C. B. Corrêa, R. Scher and R. P. M. Fernandes (2019). Antimicrobial activity of Lippia gracilis essential oils on the plant pathogen 
G.A. Ahmed, et al.,

Xanthomonas campestris pv. campestris and their effect on membrane integrity. Pesticide biochemistry and physiology, 160: 4048.

Daferera, D. J., B. N. Ziogas and M. G. Polissiou (2000). GC-MS analysis of essential oils from some Greek aromatic plants and their fungitoxicity on Penicillium digitatum. Journal of agricultural and food chemistry, 48(6): 2576-2581.

Dung, N. X., P. Van Khien, H. T. Chien and P. A. Leclercq (1993). The essential oil of Cinnamomum camphora (L.) Sieb. var. linaloolifera from Vietnam. Journal of Essential Oil Research, 5(4): 451-453.

El-Hendawy, H. H., M. E. Osman and N. M. Sorour (2005). Biological control of bacterial spot of tomato caused by Xanthomonas campestris pv. vesicatoria by Rahnella aquatilis. Microbiological research, 160(4): 343-352.

Frizzo, C. D., A. C. Santos, N. Paroul, L. A. Serafini, E. Dellacassa, D. Lorenzo and P. Moyna (2000). Essential oils of camphor tree (Cinnamomum camphora Nees \& Eberm) cultivated in Southern Brazil. Brazilian Archives of Biology and Technology, 43(3): 313316.

Fujita, Y., S. Fujita and Y. Tanaka (1974). Biogenesis of the essential oils in camphor trees. XXXI-V. On the essential oil components of a remain of Cinnamomum camphora Sieb. which was excavated at Konoyama of Moriyama, Oe-district in Tokushima Prefecture, Japan. J Agric Chem Soc Jap.

Ghalem, B. R. (2016). Essential oils as antimicrobial agents against some important plant pathogenic bacteria and fungi. In Plant-Microbe Interaction: An Approach to
Sustainable Agriculture (pp. 271-296). Springer, Singapore.

Gill, A. O. and R. A. Holley (2006). Disruption of Escherichia coli, Listeria monocytogenes and Lactobacillus sakei cellular membranes by plant oil aromatics. International journal of food microbiology, 108(1), 1-9.

Gilvaine, L., A. Eduardo, B.P. Ricardo, J.P. Fabiano and M.S. Ricardo (2012). Antibacterial activity of essential oils on Xanthomonas vesicatoria and control of bacterial spot in tomato. Pesquisa Agropecuaria Brasileira. 47(3).

Gorris, L. G. M., K. Oosterhaven, K. J. Hartmans, Y. D. Witte and E. J. Smid (1994). Control of fungal storage diseases of potato by use of plantessential oil components.

Güenther, E. (1950). 3 RD Ed. The Essential Oils.D. Van Nostrand, New York.

Hawthorne, S. B., M. L. Rickkola, K. Screnius, Y. Holm, R. Hiltunen and K. Hartonen (1993). Comparison of hydrodistillation and supercritical fluid extraction for the determination of essential oils in aromatic plants. Journal of Chromatography A, 634(2): 297-308.

Khoddami, A., H. M. Ghazali, A. Yassoralipour, Y. Ramakrishnan and A. Ganjloo (2011). Physicochemical characteristics of nigella seed (Nigella sativa L.) oil as affected by different extraction methods. Journal of the American Oil Chemists' Society, 88(4): 533-540.

Kokkini, S., R. Karousou, A. Dardioti, N. Krigas and T. Lanaras (1997). Autumn essential oils of Greek oregano. Phytochemistry, 44(5): 883886.

Laemmli, U.K. (1970). Cleavage of structural proteins during the assembly of the head of 
bacteriophage T4. Nature, 227: 680685.

Lattanzio, V., V.M.T. Lattanzio and A. Cardinali (2006). Role of phenolics in the resistance mechanisms of plants against fungal pathogens and insects. In: Imperato F, editor. Phytochemistry: advances in research, 37/661(2). Kerala, India Research Signpost, 2367.

Lin, Z. and Y. Hua (1987). Chemical constituents of 14 essential oils from Lauraceae growing in Yibin area, Sichuan Province. Linchan Huaxue Yu Gongye, 7(10): 46-64.

Lo Cantore, P., V. Shanmugaiah and lacobellis (2009). Antibacterial activity of essential oil components and their potential use in seed disinfection. Journal of agricultural and food chemistry, 57(20): 9454-9461.

Lucas, G. C., E. Alves, R. B. Pereira, F. J. Perina and R. M. D. Souza (2012). Antibacterial activity of essential oils on Xanthomonas vesicatoria and control of bacterial spot in tomato. Pesquisa Agropecuária Brasileira, 47(3), 351-359.

Matta, A. and A.E. Dimond (1963). Symptoms of Fusarium wilt in relation to quantity of fungus and enzyme activity in tomato stems. Phytopathology, 53:574-587.

McGaw, L. J., A. K. Jäger and J. Van Staden (2002). Isolation of antibacterial fatty acids from Schotia brachypetala. Fitoterapia, 73(5), 431433.

Morais, L.A.S., M.G.F. Carmo, E.C. Viegas, D.F. Teixeira, A.S. Barreto, A.P.B. Pizarro and B. Gilbert (2002). Evaluation of antimicrobial activity of extracts of medicinal plants on three tomato phytopathogens. Acta Horticulturae, 569: 87-90.

Muhialdin, B. J., A. M. Alhelli and A. S. M. Hussin (2016). The Effects of Different
Extraction Methods on Antioxidant Properties, Chemical Composition, and Thermal Behavior of. carcinogenesis, $5,7$.

Pandey, A. K., H. R. Bora, S. C. Deka, R. C. Rastogi and A. K. S. Baruah (1997). Composition of the essential oil of the bark of Cinnamomum camphora. Journal of Medicinal and Aromatic Plant Sciences, 19(2), 408409.

Pietro, L.C., S.I. Nicola, D.M. Adriana, C. Francesco and S. Felice (2004). Antibacterial Activity of Coriandrum sativum L. and Foeniculum vulgare var. vulgare (Miller) Essential Oils. J. Agric. Food Chem., 52 (26): 7862-7866.

Polizzi, G., G. Cirvilleri and A. Catara (2002). Longstanding experience in defense fungicides on grapevine in Sicily made with chemical and biological. ATTI Giornate Fitopatologiche, 2: 381-388.

Reddy, M. B., P. Angers, A. Gosselin and J. Arul (1998). Characterization and use of essential oil from Thymus vulgaris against Botrytis cinerea and Rhizopus stolonifer in strawberry fruits. Phytochemistry, 47(8), 15151520.

Russo, M., G. C. Galletti, P. Bocchini and A. Carnacini (1998). Essential Oil Chemical Composition of Wild Populations of Italian Oregano Spice (Origanum v ulgare ssp. h irtum (Link) letswaart): A Preliminary Evaluation of Their Use in Chemotaxonomy by Cluster Analysis. 1. Inflorescences. Journal of Agricultural and Food Chemistry, 46(9), 3741-3746.

Sattar, A., A. M. Gilani and M. A. Saeed (1991). Gas chromatographic examination of the essential oil of Cinnamomum camphora. Pakistan Journal of Scientific and Industrial Research (Pakistan). 
Seidel, V. and P. W. Taylor (2004). In vitro activity of extracts and constituents of Pelagonium against rapidly growing mycobacteria. International journal of antimicrobial agents, 23(6), 613-619.

Solati, Z., B. S. Baharin and H. Bagheri (2014). Antioxidant property, thymoquinone content and chemical characteristics of different extracts from Nigella sativa L. seeds. Journal of the American Oil Chemists' Society, 91(2), 295-300.

Song, W. and A. Keane (2006). Parameter screening using impact factors and surrogate-based ANOVA techniques. In 11th AIAA/ISSMO Multidisciplinary Analysis and Optimization Conference (p. 7088).

Stall, R.E. (1993). Xanthomonas. In: Swings J.G., Civerolo E.L. (eds). Xanthomonas, pp. 57-60 Chapman and Hall, London, UK.

Tabanca, N., N. Kırımer and K.H.C. Baser (2001). The composition of essential oils from two varieties of $S$. erytrantha var. erytrantha and cedretorum. Turkish Journal of Chemistry 25: 201208.

Takaoka, D., K. Takaoka, T. Ohshita and M. Hiroi (1976). Sesquiterpene alcohols in camphor oil. Phytochemistry 15, 425-426.

Tao, G., A. Lu, Z. Jiang, H. Chen, X. Zhang, H. Sun and Y. Wu (1987). New resource plants of natural camphor and linalool. Zhiwu Xuebao, 29(5), 541548.

Tarantilis, P. A. and M. G. Polissiou (1997). Isolation and identification of the aroma components from saffron (Crocus sativus). Journal of Agricultural and Food Chemistry, 45(2), 459-462.

Towsend, G.R. and J.W. Heuberger (1943). Methods for estimating losses caused by diseases in fungicide experiments. Plant Disease Reports24: 340-343.

Tuzun, S., M.N. Rao, U. Vogli, C.L. Schardl and J.A. KU (1989). Induced systemic resistance to blue mold, early induction and accumulation of $\beta$ 1, 3-gluconases chitinases and other pathogenesis -related proteins (bproteins) in immunized tobacco. Phytopathology, 79:979-983.

Van Loon, L.C. (1997). Induced resistance in plants and the role of pathogenesisrelated proteins. European Journal of Plant Pathology. 103: 753-65.

Ward, E.R., S.J. Uknes, S.C. Williams, S.S. Dincher, D.L. Wiederhold, D.C. Alexander, P. Ahl-Goy, J.P. Me'traux and J.A. Ryals (1991). Coordinate gene activity in response to agents that induce systemic acquired resistance. Plant Cell 3: 1085-1094. 
تحليل الكروماتوجرافي الغازي (مطياف الكتلة) GC-MS لثلاث زيوت أساسية نباتية وتأثيرها على مرض التبقع البكتيري للطماطم

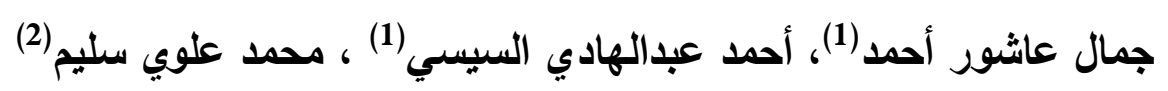

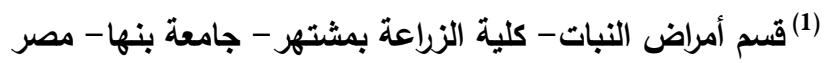

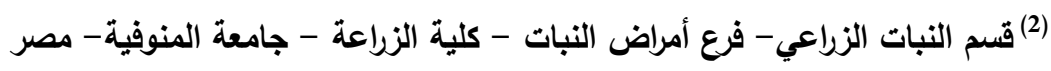
الملخص العربي

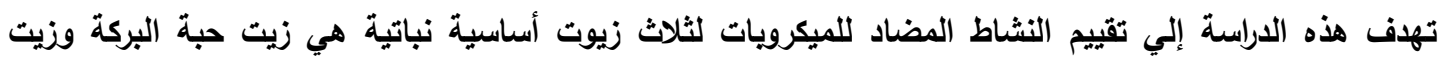

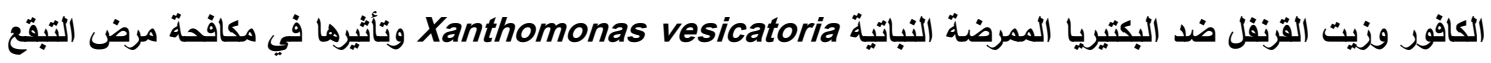

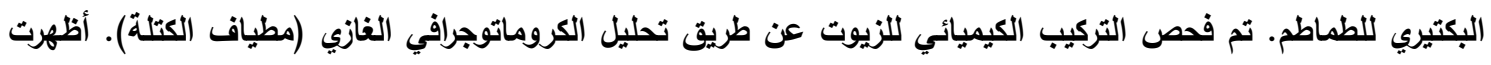

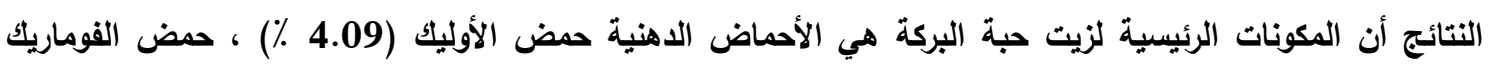

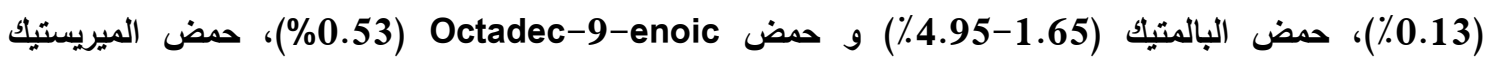

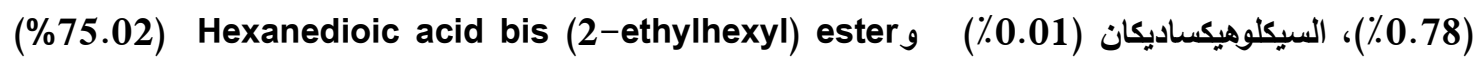

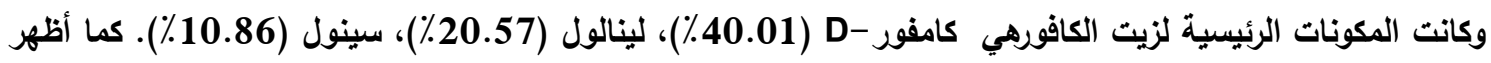

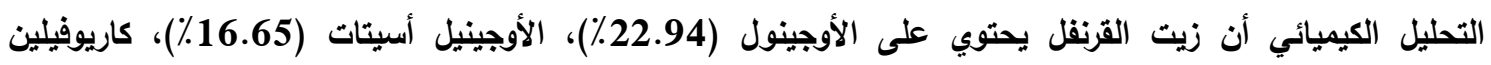

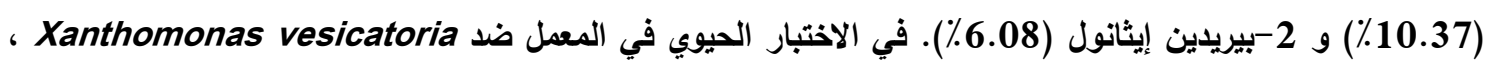

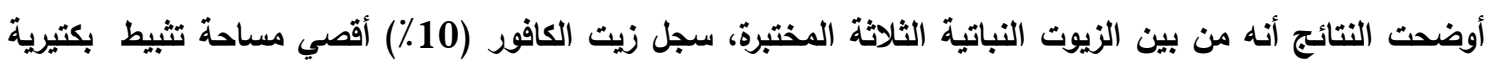

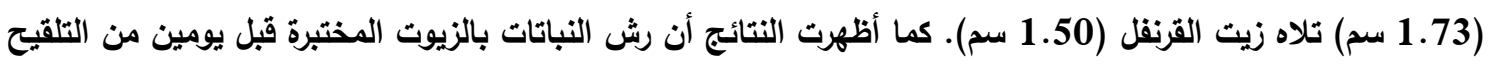

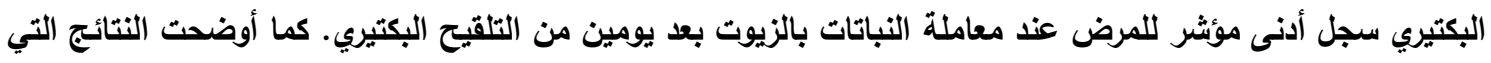

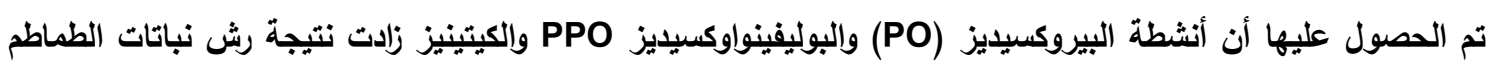

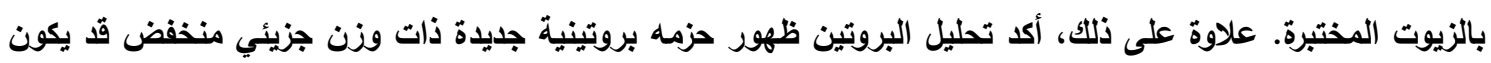
لها علاقة بتقليل شدة المرض على النباتات المعاملة بالزيوت المختبرة. 